Marta Morán Álvarez

Isabel Gil Gabernet

Revista

Xavier Payà Mercé

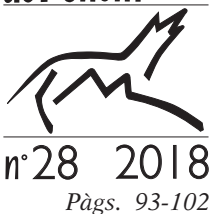

DOI.10.21001/rap.2018.28.8

Universitat de Lleida

ISSN: $1131-883-\mathrm{X}$

ISSN electrònic: $2385-4723$

www.rap.udl.cat

\title{
L'arqueologia a Lleida en l'última dècada. A propòsit de la Ilerda romana
}

\section{Archaeology in Roman Lleida (Ilerda) in the last decade}

En aquest article donem a conèixer les darreres novetats obtingudes a partir de les excavacions que s'han fet a la ciutat per al període romà. Donem especial relleu a la representació gràfica dels resultats. La utilització de programes de tractament de dades GEO localitzades (SIG) o la recreació en 3D de les estructures descobertes formen part també dels objectius als quals volem arribar a curt termini, per tal de facilitar la difusió i comprensió del discurs històric.

Paraules clau: arqueologia urbana, georeferenciació, visor, banys, metal-lúrgia, dipòsits votius, Ilerda.
The present article presents the most recent findings of the archaeological excavations carried out in Roman Lleida (Ilerda). Graphic representation of the results play an important function. The use of geographic information techniques such as GIS and 3D reconstruction are exceptional analytic and learning tools that play a role in the spread and understanding of history.

Keywords: urban archaeology, georeferencing, viewer, Roman baths, metallurgy, oblations, Ilerda. 


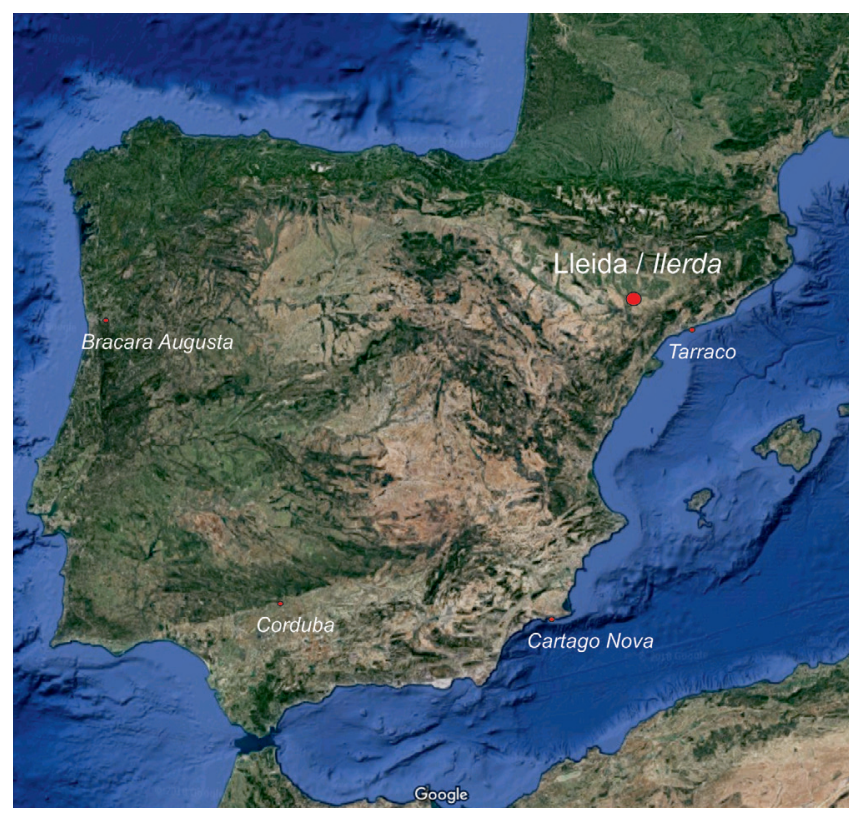

Figura 1. Localització d'Ilerda i altres ciutats de la Hispània romana.

\section{L'arqueologia preventiva a Lleida, una etapa consolidada}

La Secció de Patrimoni Cultural Històric i ArtísticArqueologia, dependent de la Regidoria de Promoció i gestió de l'hàbitat urbà i rural i la sostenibilitat, gestiona des de l'any 1992 de manera delegada el patrimoni arqueològic del municipi de Lleida. La seva funció principal és el control de les obres de construcció que afectin el subsol de la ciutat històrica i en el seu cas, l'excavació i la recuperació de tota la informació existent. En tots aquests anys el nombre d'intervencions al jaciment s'ha anat incrementant de forma proporcional, doncs, a la reconfiguració urbanística de la ciutat.
Gràcies a aquest treball el coneixement de les principals fases històriques ha millorat de manera important $\mathrm{i}$ ens ha permès també incorporar espais de comprensió històrica i de difusió patrimonial.

Aquesta dinàmica ens ha facilitat, d'altra banda, la contextualització de totes aquelles notícies que, entorn de la ciutat, diferents historiadors havien anat recopilant a partir sobretot de les fonts clàssiques (Payà i Pérez 2005). El coneixement d'espais de gaudi públic, el traçat dels principals eixos de la ciutat, el seu marc topogràfic així com temporal, ja no són pura suposició sinó que tenen un reflex en el registre arqueològic. Intervencions realitzades fora del que tenim identificat com a recinte de la ciutat romana ens ajuden a refermar-nos en l'espai que ocupava Ilerda gràcies a criteris d'absència/presència de materials i estructures.

A partir del 2010, però, aquesta dinàmica s'atura. La manca d'iniciatives immobiliàries públiques $\mathrm{i}$ privades al centre històric implica una minva en les excavacions. La conseqüència és les poques novetats a afegir sobretot pel que fa al període romà.

Si més no, com a dada positiva hem de declarar que això ens ha permès fer una reflexió sobre l'explotació del que fins ara havíem recuperat. Hem fet contribucions en simposis i/o publicacions, i hem donat a conèixer per exemple produccions ceràmiques pròpies de la ciutat com les de les engalbes, destinades a cobrir la demanda de vaixella d'ús comú, tot i que de vegades també imiten produccions d'importació com el vernís negre, o les formes de sigil.lada aretina o sud-gàl-lica (Morán i Payà 2007: 187-234).

També ha estat possible identificar tallers locals de terra sigil.lada a partir d'elements pròpiament productius com són els motlles. L'anàlisi comparativa de l'argila ha confirmat aquesta nova fita per l'arqueologia clàssica a la ciutat (Buixeda i altres 2014).

Un temps per a la reflexió que ens ha dut per altres camins i en direcció vers la difusió del patrimoni i la millora de les eines per fer aquesta difusió.

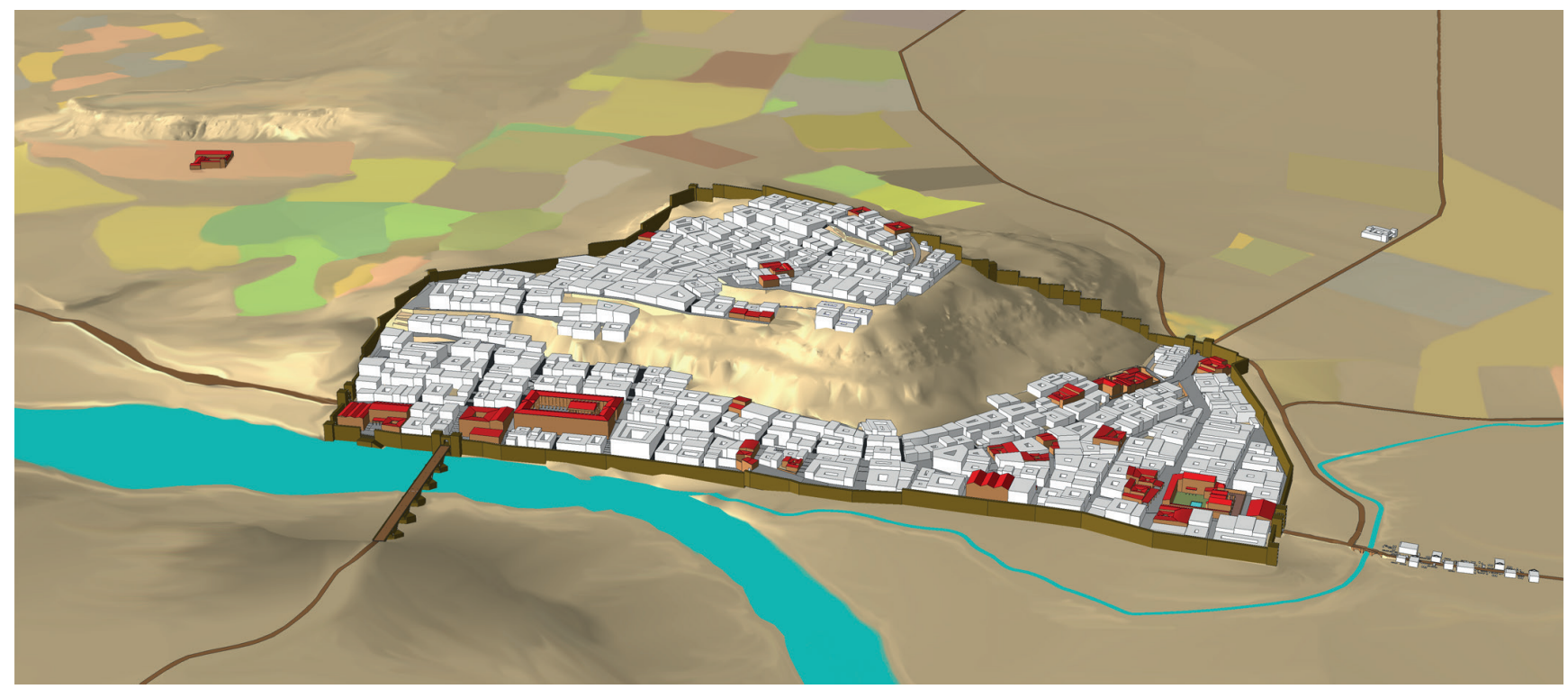

Figura 2. Proposta de restitució d'Ilerda al segle II dC. Els elements grafiats corresponen a llocs d'on s'han recuperat restes arqueològiques. 


\section{L'arqueologia i l'estudi de l'evolució urbanística a les ciutats}

Els darrers anys, una de les tasques que hem dut a terme des d'aquesta secció és la d'intentar fer una reconstrucció de l'urbanisme antic en les diferents fases històriques. Aquesta no és una feina exclusiva de la

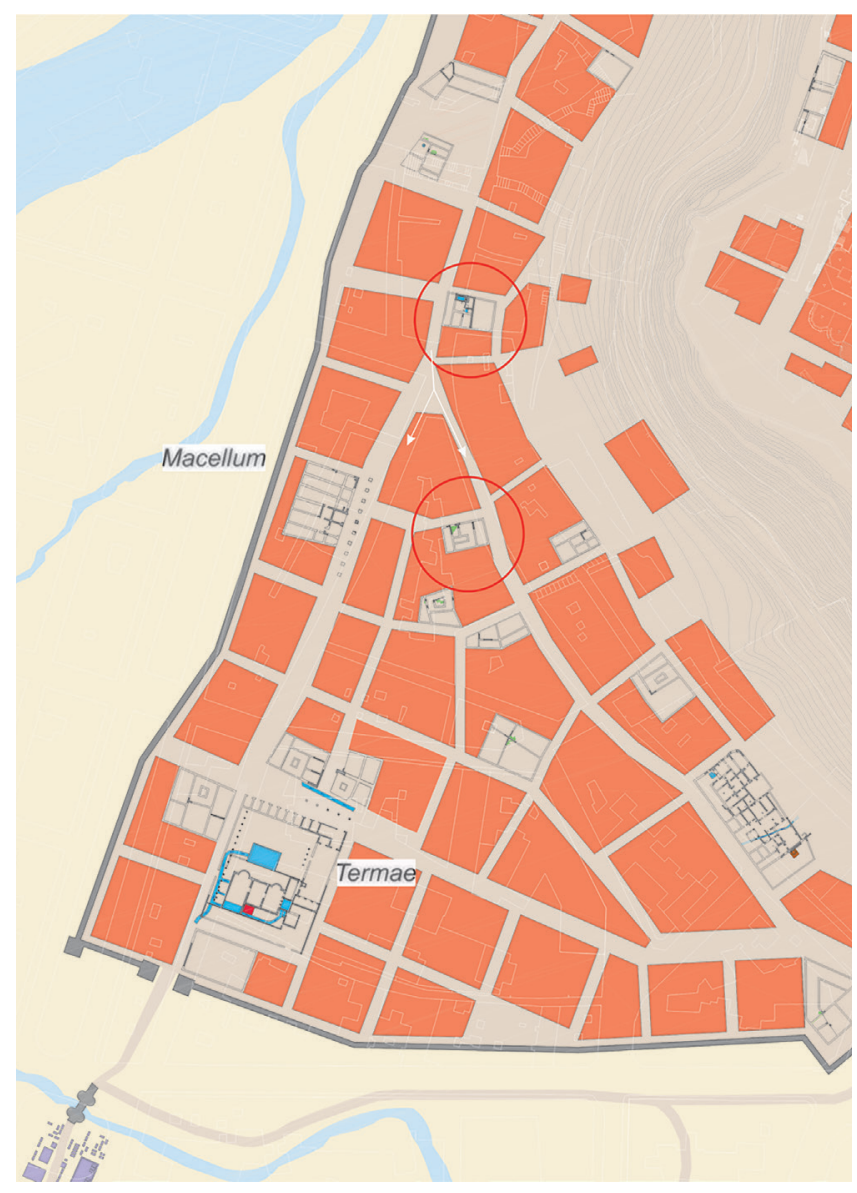

Figura 3. Comparativa entre el traçat de carrers en la ciutat actual i les illes resultants en època romana. nostra secció. En altres ciutats on hi ha una gestió centralitzada de les dades arqueològiques, aquesta feina és fonamental per a la comprensió global del jaciment. Alguns serveis municipals, com és el de Barcelona, disposen a més a més d'eines a l'abast de qualsevol a través del web perquè els interessats puguin consultar les dades de cadascuna de les excavacions i amb una base de dades geolocalitzada (es pot accedir a aquest web a: <http://cartaarqueologica. bcn.cat/>). Així mateix, ciutats amb un important patrimoni històric com Còrdova tenen visors que faciliten aquest accés a dades concretes (<http://www. gmucordoba.es/visorcasco/arqueologia.html >).

Des d'una gestió més modesta, nosaltres estem posant els fonaments per poder comptar també amb un sistema d'informació geogràfica que implementi dades històriques, material gràfic i interpretació urbanística. Des del web del nostre Ajuntament es pot accedir a un visor temàtic de l'arqueologia de la ciutat per consultar-hi l'evolució històrica, els perímetres emmurallats i informació sobre algunes intervencions arqueològiques realitzades ja fa un temps $(<\mathrm{https} / / /$ cartolleida.paeria.es/planol_arqueologia/ $>$ ).

D'altra banda, partint de les estructures trobades, les cotes d'ús i la seva situació, intentem fer una comprensió global del funcionament urbà, tenint en compte, sobretot, la base topogràfica prèvia. El resultat són una sèrie de plànols en $3 \mathrm{D}$ en els quals es poden identificar els habitatges, els edificis públics i els carrers que hem tingut oportunitat d'excavar, a més d'una proposta d'organització a partir de l'extrapolació de les dades de les illes resultants. Es tracta d'unes imatges de les quals es pot treure un veritable rendiment per a la difusió del nostre patrimoni. La realització d'aquest treball ens fa reflexionar, així mateix, sobre els canvis que es produeixen a causa del transcurs del temps.

Després d'uns anys d'anàlisi, hem pogut arribar a diferents conclusions. En general, es pot constatar un desplaçament dels eixos viaris i la transformació de les terrasses.

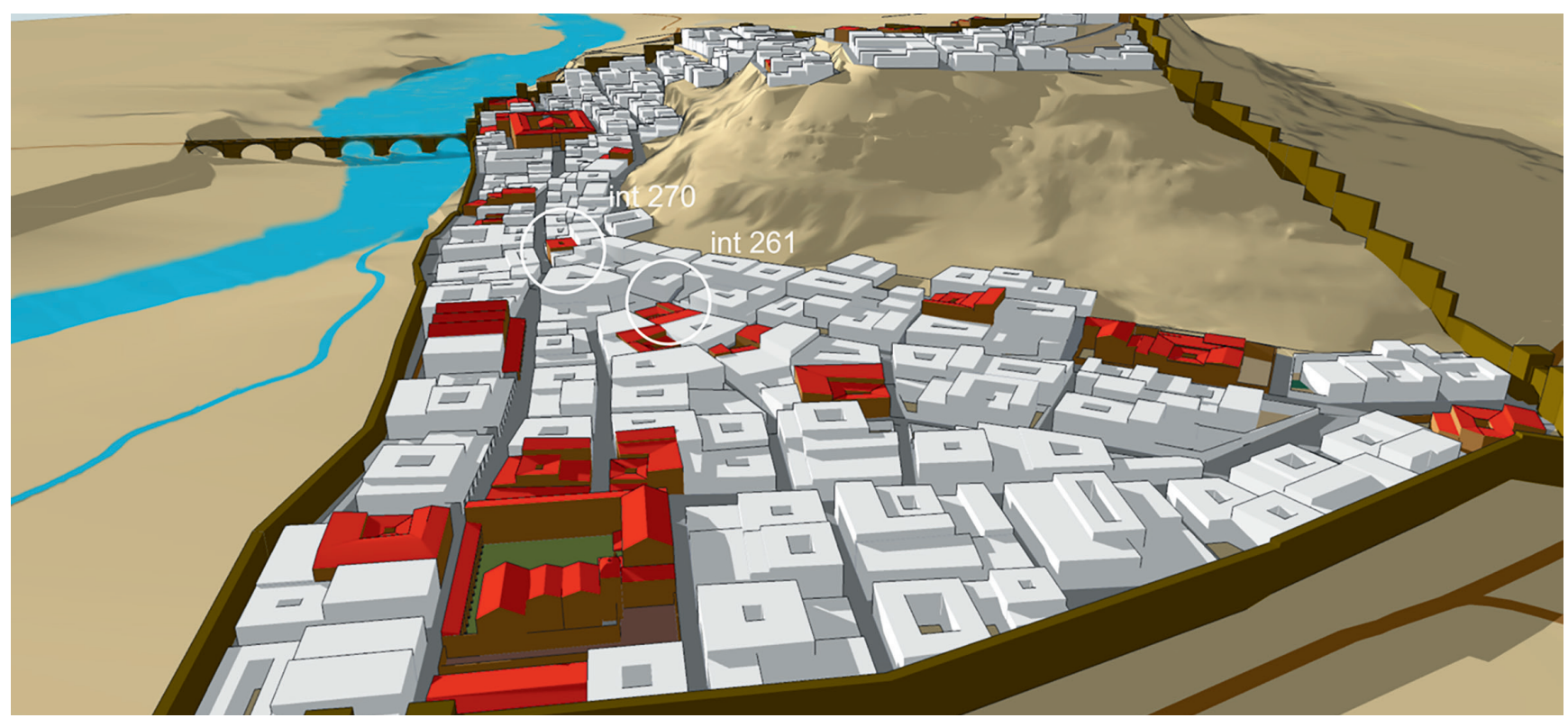

Figura 4. Detall de l'angle oriental de la ciutat on han estat més nombroses les intervencions. Els dos cercles assenyalen les dues excavacions d'on s'aporten les novetats. 
Partint de la base que la topografia prèvia marca de manera important la implantació urbanística, sabem també que hi ha una variació notable entre el traçat dels carrers d'època romana $i$ els de les fases posteriors. La configuració actual obeeix sobretot a l'organització en època andalusina. En el plànol que acompanya, podem veure el traçat urbà actual sobre les illes resultants d'època romana i el seu desplaçament.

També sabem que les cotes han variat depenent del lloc. Per exemple, mentre que els nivells d'ús a la zona de les termes s'han mantingut fins a l'actualitat, en d'altres, com la coneguda domus que es troba als soterranis de l'auditori municipal, els paviments estan 4 metres per sota del carrer actual.

Les terrasses que ocupaven els habitatges d'època romana semblen més amples i es veuen totalment transformades en èpoques posteriors.

El triangle que forma la desembocadura del riu Noguerola amb el Segre i el turó de la Seu és l'espai on es concentren la major part de les troballes, un lloc que a més a més és més favorable per a la instal.lació urbana. A mesura que ens encaminem vers l'oest, la distància entre el riu i el desnivell del turó es va fent més petita i només el pont que travessa el Segre fa de pol d'atracció per a una sèrie d'equipaments bàsics com podrien ser el fòrum o el port fluvial.

\section{L'arqueologia a Lleida des del 2005 i les troballes d'època romana}

Des del 2005, s'han realitzat un centenar d'actuacions arqueològiques, les quals no sempre s'han traduït en resultats positius i menys encara per l'època que tractem aquí.

Percentualment, la major part de les restes documentades pertanyen al món feudal, seguides a curta distància per les de la fase moderna i contemporània. Pel que fa a les restes d'època romana, les troballes es redueixen dràsticament. D'aquest moment només podem parlar de dues grans intervencions arqueològiques, la primera realitzada l'any 2006 al carrer Magdalena, 14-16 (int 261) i la segona del 2010 al carrer del Carme, 7-17 (int 270). En aquest sentit no inclourem aquí notícies esporàdiques sorgides a partir de seguiments d'obra, les quals tenen evidentment una limitació física i interpretativa bastant alta.

Aquestes dues intervencions són rellevants també perquè estan vinculades amb sengles fets originals. L'un està relacionat amb els rituals fundacionals i l'altre amb una indústria necessària per al desenvolupament de la vida diària. Ambdues estan situades en el que esdevindrà el barri de Magdalena, i ens ajuden a reconstruir l'urbanisme de la ciutat amb l'avantatge que es troben, si més no, properes.

\section{Int 261. Carrer Magdalena, 12-14}

Situada en l'antic barri de Magdalena, en una zona propera a l'encreuament amb el carrer del Carme, aquesta intervenció va aportar una successió temporal força interessant, ja que parteix d'uns nivells sense estructures però amb materials tardoibèrics. Passen per diferents etapes del període romà, republicà $i$ d'August i arriben finalment al període baiximperial.

Els elements més antics en context són dos retalls a les sorres naturals, recremats i plens de sorres. Aquests retalls presents també en altres intervencions han de tenir relació amb possibles forns per transformar els minerals de ferro. Són típics al voltant de començaments del segle I abans de Crist.

La primera implantació urbanística la trobem entorn del 80-50 aC. Es tracta de dos murs paral.lels fets amb còdols i que es relacionen amb una pavimentació de terra piconada. És una construcció molt semblant a la que es va trobar fa uns anys al carrer de l'Aiguardent. Sembla que aquesta tipologia constructiva és freqüent en aquests primers testimonis de

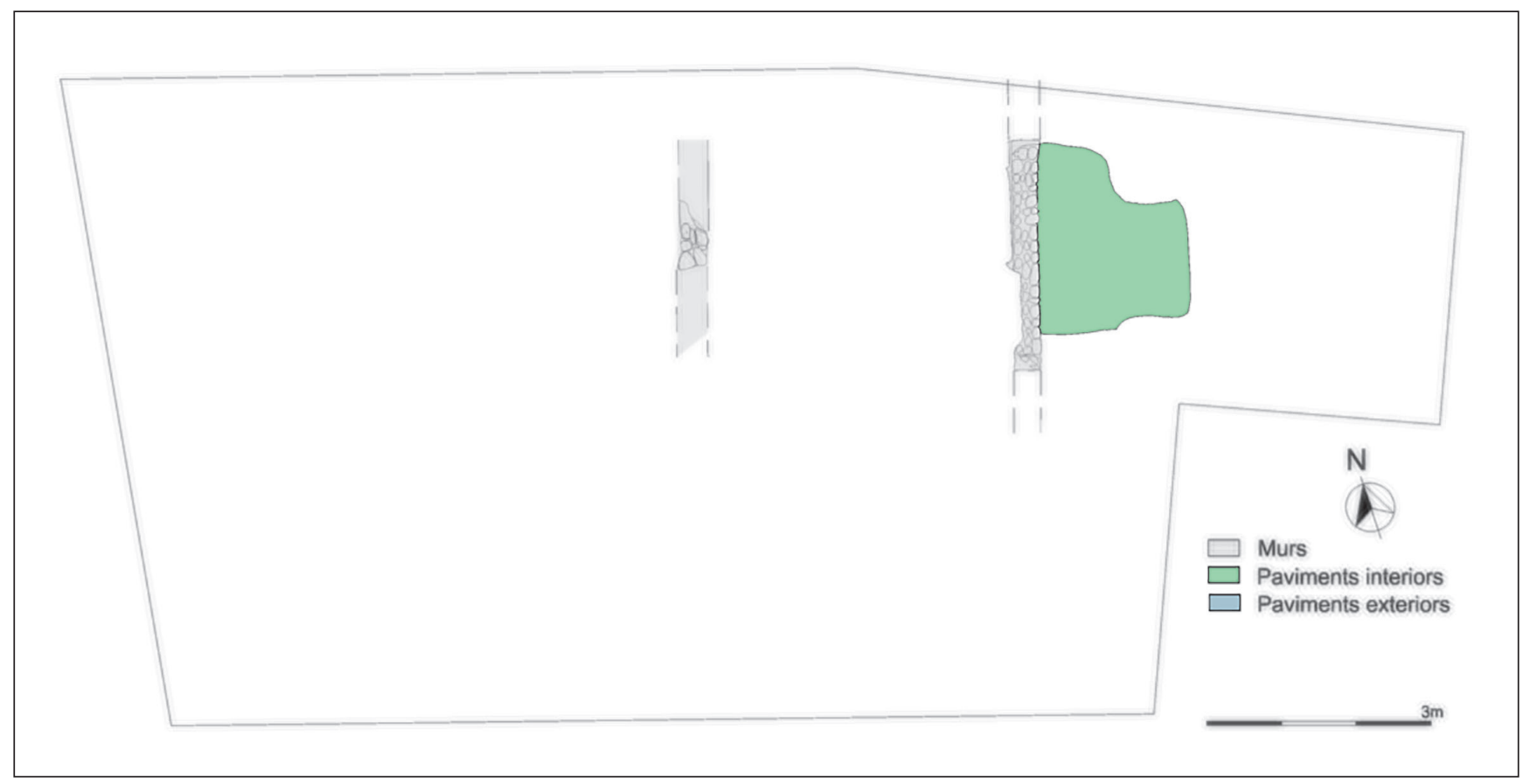

Figura 5. Int. 261 Carrer Magdalena, 14-16. Fase republicana. Segle I aC. 


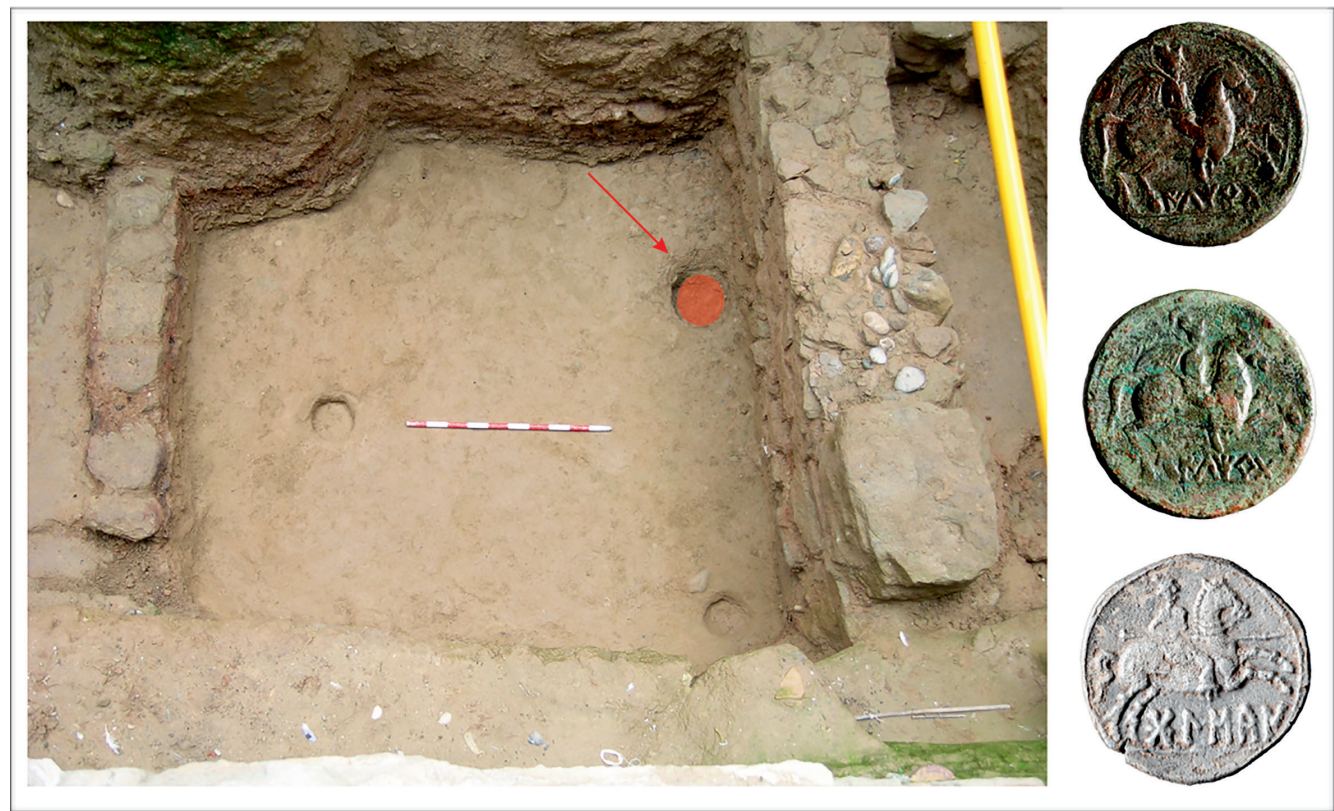

Figura 6. A la imatge, els tres forats practicats a les graves. El grafiat és el que contenia les tres monedes.

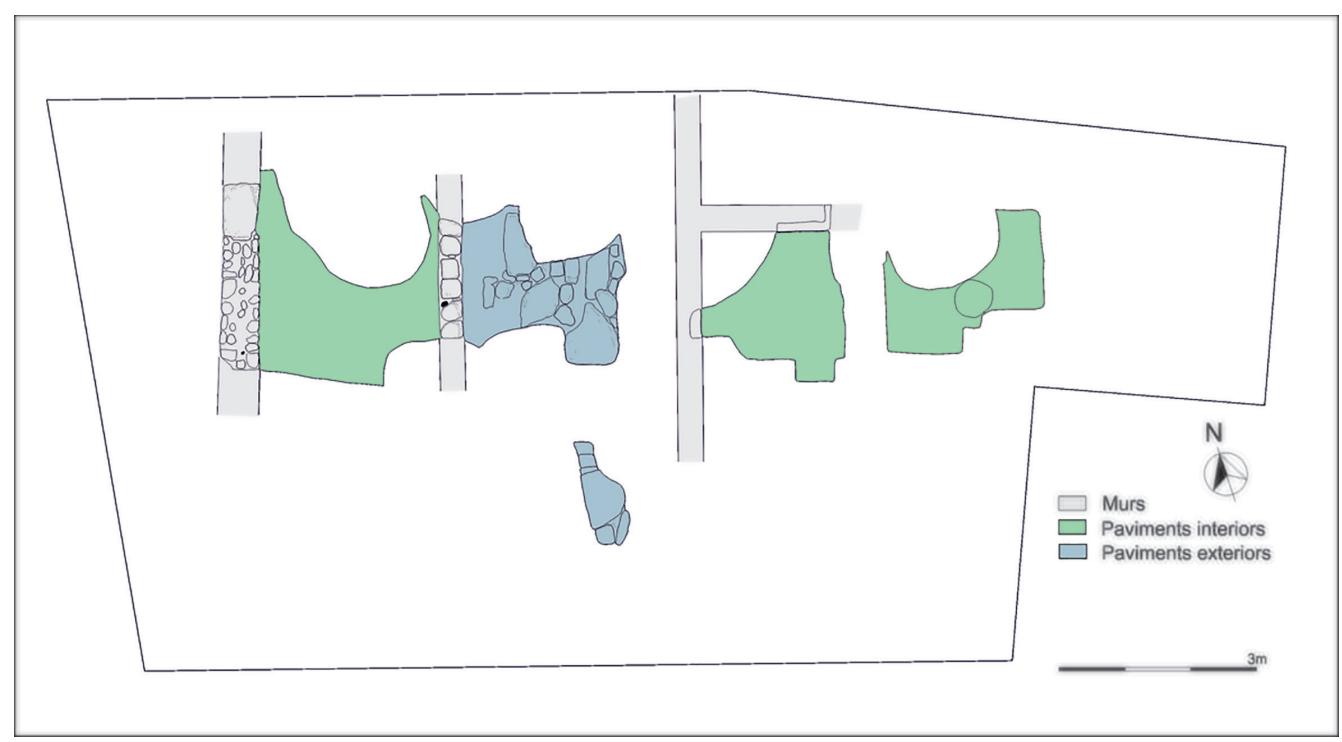

Figura 7. Int 261 Carrer Magdalena 14-16. Fase de l'època d'August. Canvi d'era.

construcció. La distància entre ambdós és de 4 metres i el material, típic del moment, ens parla d'àmfores olieres procedents de l'Apulia i campanianes B-oides.

La següent fase s'inicia amb un fet de cert caràcter excepcional. Just al costat d'un dels murs més gruixuts construïts en aquest moment i possiblement de manera simultània, es practiquen tres retalls circulars al terra de forma equidistant. Un d'aquests retalls acull tres monedes, dues de les quals són de bronze i procedeixen de la seca d'Iltirta, concretament són unitats de la cinquena emissió amb datació en el trànsit entre el segle II i I aC, i la tercera és un denari de bronze de la seca de Bolskan, a més a més de diversos fragments de ceràmica de parets fines.

La disposició equidistant dels tres forats i el fet que retallen les graves del terreny natural, al costat del mur de majors proporcions, ens refermen en considerar la troballa com un acte fundacional.
Existeixen molts articles que tracten sobre els rituals fundacionals tant de les ciutats com pel que es refereix a edificis concrets que tinguin un caràcter públic o privat.

A Valentia han recollit diferents exemples, com ara restes de banquets, monedes o ceràmiques en zones molt concretes com poden ser les fonamentacions de murs o l'encreuament de carrers (Ribera 2010: 272).

A la mateixa Ilerda, tot i que en un context posterior (segle $\mathrm{II} \mathrm{dC}$ ), trobem enterraments infantils sota paviment i urnes que contenen ous que poden tenir també aquest sentit apotropaic (Pérez Almoguera 1998: 196).

En aquest sentit recuperem també la troballa de l'any 1998 de les restes de cornamenta de cèrvid que aparegueren en els nivells inicials d'una construcció domèstica, que vam datar al segle I $\mathrm{dC}$, en una excavació no gaire llunyana, al carrer de la Parra (int 98). 


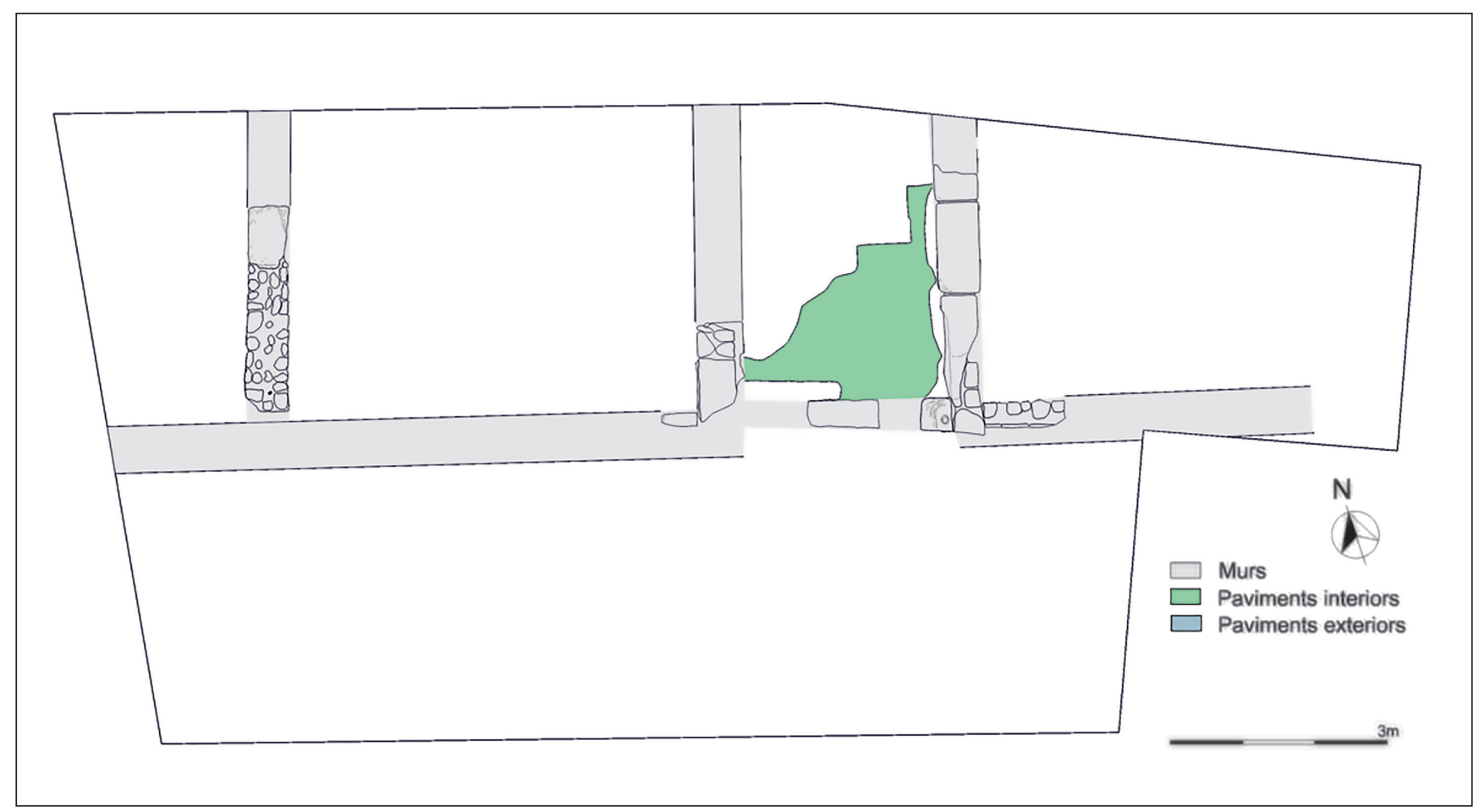

Figura 8. Int. 261 Fase Altimperial. Segles I i II dC.

Acompanyava en l'estrat una pàtera de ceràmica reduïda, una producció local que imita peces de vernís negre.

El descobriment de deposicions d'elements faunístics, generalment de caràcter domèstic, és freqüent ja des de fases anteriors. Un exemple proper també podria ser la col-locació d'un cap de cavall en la rasa de fonamentació d'un mur que pertanyia a un llogaret d'inicis del segle segon abans de Crist a 5 km d'Ilerda (Equip Sarró 2000: 149).

Malgrat que el solar on vam actuar era de petites dimensions, podem parlar d'una implantació urbana ja consolidada a inicis del segle I aC. Hi ha, doncs, una ordenació regular dels espais separats per murs de diferents gruixos que permeten distingir entre el que devien ser les parets mestres o la possible façana i els envans de compartimentació. Els espais resultants varien entre els 3,21 i els 2 metres d'amplada.

La relativa llunyania d'altres estructures coetànies, però, no permet entendre el funcionament de les illes de cases.

Tot i que generalment els sòls es fan de terra piconada, aquí es construeix un espai pavimentat amb lloses que potser ens remet a l'existència d'un pati.

Poc temps després, l'habitatge sofrí un incendi a conseqüència del qual, part de l'arrebossat d'argila d'un dels envans localitzats es va consolidar i endurir tant que n'afavorí la conservació.

Els materials recollits no varien gaire de la fase anterior, és a dir, hi ha un gran percentatge d'importacions itàliques encapçalades pel vernís negre procedent del Laci, acompanyades per les àmfores vinàries de la Campània i les interpretacions locals de la vaixella de vernís negre que arriba en produccions d'engalba vermella i negra (Morán i Payà 2007: Bol M i P 3400).
De les construccions anteriors a l'alt Imperi només sobreviu el mur que fa de límit de façana de carrer. En aquest s'aprecia el moment de recreixement i reconstrucció a l'alçat. Contràriament, els murs que s'erigeixen ara són de grans blocs de pedra sorrenca similars als localitzats en excavacions properes com la del carrer de l'Aiguardent.

En aquest moment la distribució dels espais s'articula de manera diferent formant un mínim de quatre espais un dels quals disposa d'una porta que dona accés a un cinquè espai. A falta de més informació l'espai podria ser també un carrer perpendicular al traçat del carrer Magdalena.

Tot i documentar-se diferents usos, aquesta distribució continuarà igual fins a arribar al baix Imperi.

\section{Int 270. Carrer del Carme 9-11}

Excavada en 2010, aquesta intervenció aporta interessants dades sobre la topografia i la successió històrica al solar. Tenim continuïtat d'hàbitat des del segle I aC fins a l'actualitat. Els elements més destacables són, però, les restes d'un balnea domèstic d'importants dimensions que no es pot posar en relació amb una casa concreta, ja que només han sobreviscut els elements que se situen per sota de la cota de circulació.

En aquest bany privat es distingeixen perfectament el mur que tanca l'hipocaust i la piscina del frigidari (una banyera de metre quadrat). A través del mur que tanca l'hipocaust i en el lloc per on s'alimentava el foc es poden veure les pilae de suport i la part inferior de les suspensurae. Al mur de l'hipocaust es pot veure també una estreta espitllera per on els conductes, segurament de plom, transportaven l'aigua 


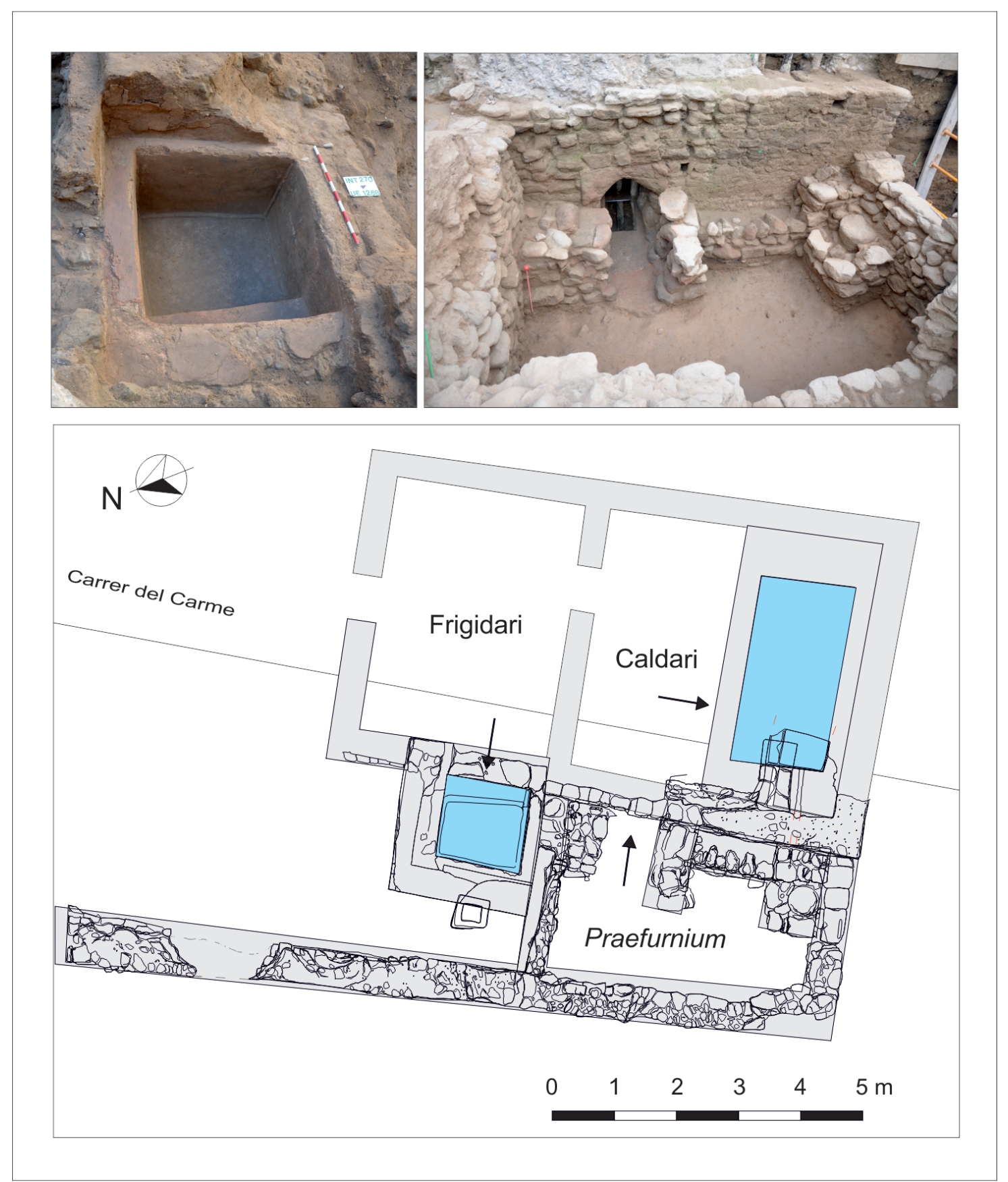

Figura 9. Int 270. Carrer del Carme, 9-11. Planta i restitució d'unes termes domèstiques.

calenta de la caldera fins a l'interior de la piscina del caldarium. La disposició d'aquests elements ens suggereix que l'habitatge es perllongava més enllà del límit del carrer actual i per tant ens plantegem una disposició urbanística diferent.

Si els materials ens donen una data del segle II dC per a la construcció d'aquests banys, la fase final d'utilització arriba al segle v dC.

$\mathrm{Al}$ mateix solar, però possiblement independent d'aquesta domus amb banys, trobem un àmbit que ha sofert grans alteracions i del qual podem apreciar només dos murs perpendiculars dels quals un es conserva en part. Aquests murs aparentment d'època d'August (fets de grans blocs rectangulars de pedra sorrenca que es combinen amb trams de maçoneria) semblen contenir a dins unes altres estructures amb una funcionalitat concreta. Però no és així; tot i que la disposició de les fosses sembla resseguir els murs, aquests són estratigràficament posteriors i es relacionen amb un moment que les fosses estan amortitzades i que culmina amb la construcció d'un paviment.

Ens centrem, però, en les estructures excavades al terreny natural que adopten la forma de cubeta circular. Hem de parlar de tres tipus diferents.

El primer tipus són cubetes de planta circular sense cap estructura conservada al voltant. El seu diàmetre oscil.la entre els 35 i els $45 \mathrm{~cm}$. La base no es troba rubefactada així com tampoc les parets. Una d'elles conté un canal de $80 \mathrm{~cm}$ de llargada.

El segon tipus són cubetes en les quals es van trobar restes de combustió i que estaven envoltades 


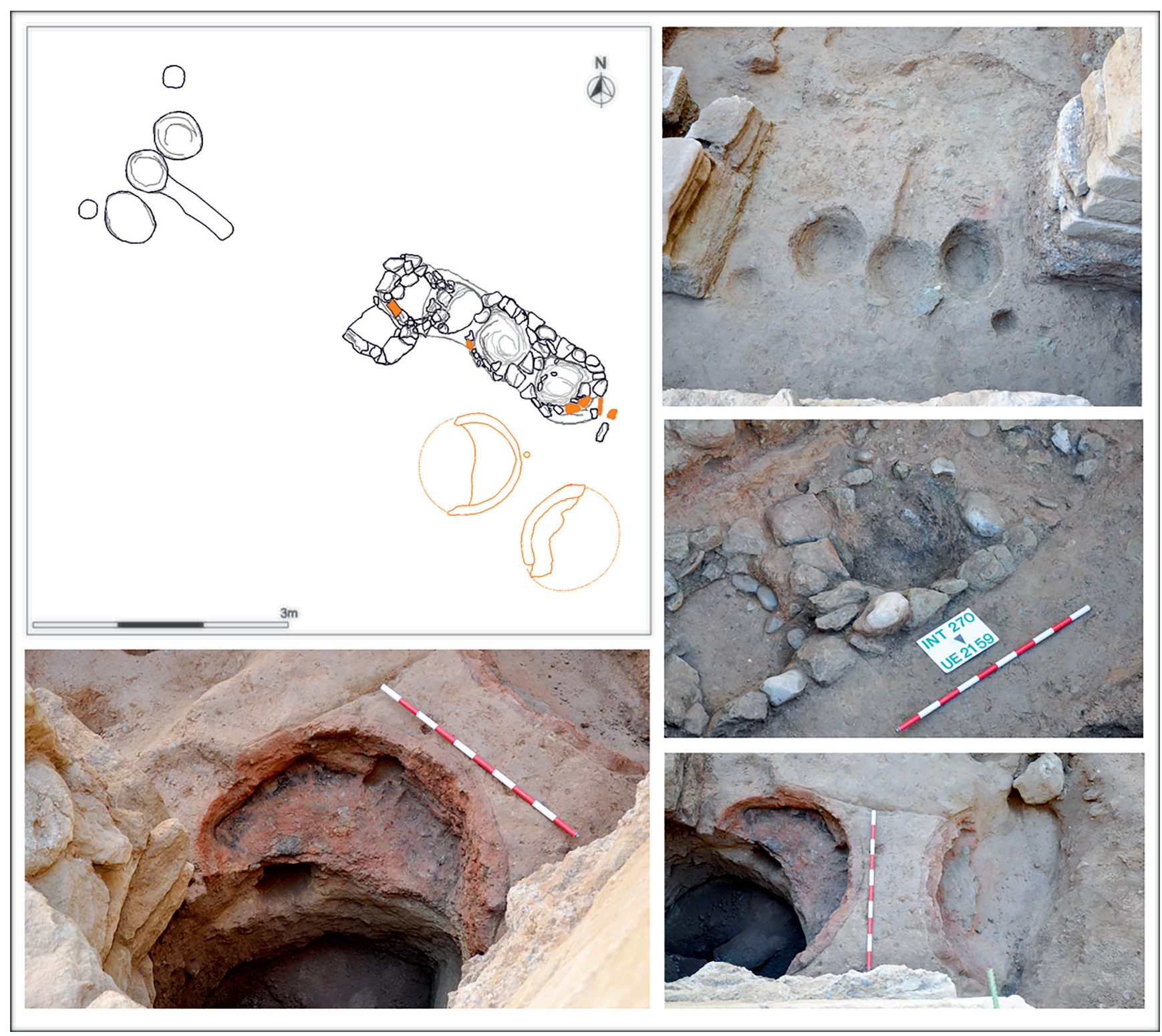

Figura 10. Int 270. Planta i detalls dels retalls practicats a l'argila pertanyents a possibles forns de fusió.

de pedra. Com les anteriors, el diàmetre s'aproxima a una mitjana de $40 \mathrm{~cm}$ i respecte a la superfície estan excavades uns $30 \mathrm{~cm}$ per sota del nivell que les envolta.

Finalment, les del tercer tipus tenen un diàmetre major (aproximadament 1,20 m) i estan recobertes amb argila, que els dona un aspecte més acurat. Una d'aquestes conserva l'orifici per on s'introduirien les toveres per tal d'aportar oxigen i augmentar la combustió.

La interpretació d'aquestes cubetes és encara provisional. A falta d'una anàlisi definitiva de les mostres recollides en excavació, hem de suggerir que ens trobem davant d'un lloc de transformació de mineral de ferro.

Els forns utilitzats en aquesta activitat varien depenent de la tècnica emprada. Normalment disposaven d'una estructura que sobresurt del terreny en forma de xemeneia. Aquesta té sovint un diàmetre inferior a la part de dalt i de vegades dues obertures laterals per on s'introduïen les toveres que amb les manxes contribuïen a augmentar la temperatura de la combustió. Aquests forns de fusió podien tenir un accés per al sagnat de l'escòria, és el que es denomina canal.

L'explotació de recursos com el ferro està prou repartida per tot el territori (Vázquez et al. 2005: 129). Hi han diferents orígens a l'hora de recollir i explotar aquest mineral però una altra dada a tenir en compte i molt important, gairebé fonamental, és la presència abundant de combustible per tal de poder dur a terme aquesta activitat de transformació. D'una altra banda, la presència propera d'aigua també resulta molt important. En ambdós casos aquestes premisses es compleixen. D'una banda, el proveïment de fusta sembla assegurat, ja que també se n'empra a les termes privades. La presència d'aigua, d'altra banda, és 


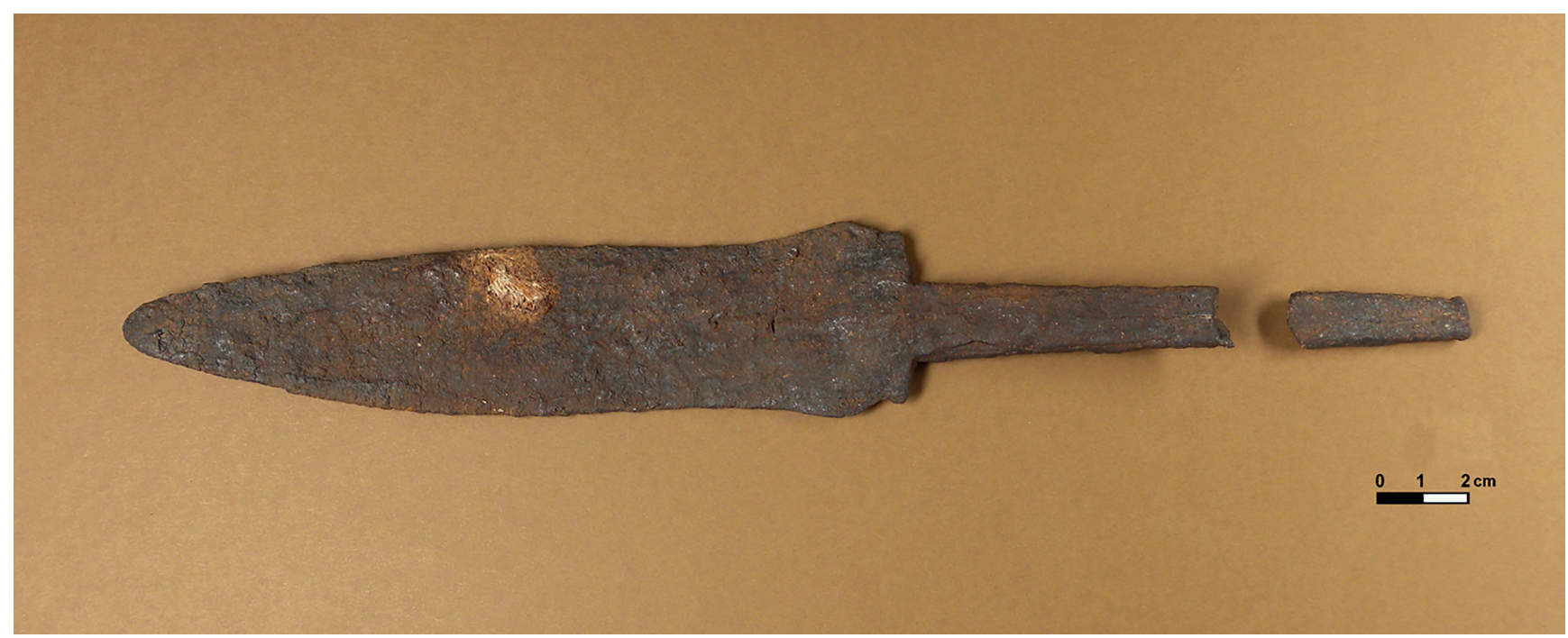

Figura 11. Int 270. Puggio o punyal trobat a la intervenció i en procés de restauració.

coneguda a la zona. Tant és així que als voltants es van muntar posteriorment unes adoberies alimentades per aigua subterrània que avui dia continua fluint. D'aquesta manera no és gens estrany que ens trobem davant d'una ferreria on, si més no, es podrien fer treballs de forjat. Un exemple d'aquests treballs podria ser el punyal o puggio trobat en aquest mateix indret i que encara resta en procés de restauració.

La finalització dels estudis d'aquesta intervenció ens ajudarà, doncs, a confirmar la hipòtesi sobre la utilització d'aquests forns.

El coneixement de la Lleida romana té molts punts encara per resoldre, com també el de les etapes històriques posteriors. La implementació dels plànols on figuren restituïdes les restes excavades és una feina que requereix una revisió permanent i que ens serveix per comunicar a diferents tipus de públic el treball que es desenvolupa des de la secció. Aquesta visió global forma part de la perspectiva necessària per arribar a comprendre passat i present.

\section{Marta Morán Álvarez Isabel Gil Gabernet Xavier Payà Mercé}

Arqueòlegs de l'Arxiu Arqueològic. SPHCA Ajuntament de Lleida Av. Fontanet núm 26 - 25001 Lleida mmoran@paeria.es 
Buxeda i Garrigós, J., Madrid i Fernández, M., Morán Álvarez, M., Payà i Mercé, X., Pérez Almoguera, A. (2014). La terra sigillada d'Ilerda, caracterització arqueomètrica i estudi històric-arqueològic de la seva producció i de la seva relació amb les ceràmiques engalbades. A: M. Roca, M. Madrid, R. Celis (eds.). Contextos cerámicos de Época Altoimperial en el Mediterráneo occidental. Barcelona: 182-249.

EQuip SARRó (2000). Les Roques del Sarró (Lleida, Segrià): evolució de l'assentament entre el 3600 cal. ane i el 175 ane. Revista d'Arqueologia de Ponent, 10: $103-173$.

Gil, I., Loriente, A., Morán, M., Payà, X., Pérez, A. (2001). De la Iltirta prerromana a la Ilerda tardorromana. Nuevos datos tras dos décadas de investigación continuada en Lérida. Archivo Español de Arqueología, 74, 183-184: 161-181.

Iborra Eres, M. P., Guillem Calatayud, P., Grau Almero, E., Ribera i Lacomba, A. (2013). El pozo votivo fundacional de L'Almoina (Valencia, siglo II a.C.). Estudio del material paleobiológico. Proyecto Valentia-Pompeia: Economía y medio ambiente en dos ciudades de época republicana. A: Animals $i$ arqueologia hui. I Jornades d'arqueozoologia. Museu de Prehistòria de València. Valencia: 305-322.

Morán Álvarez, M. (2011). INT- 261. Carrer Magdalena 14-16. Memòria de la Intervenció, 20 de juny al 31 de desembre de 2008, memòria inèdita. Lleida.

Morán Alvarez, M., Payà Mercè, X. (2007). La vaixella de taula engalbada de la ciutat romana d'Ilerda i el fenomen de les imitacions durant el període tardorepublicà i altimperial. A: Les imitacions de vaixella fina importada a la Hispania Citerior (segles I aC - I dC). Taula Rodona Imitatio Vasaria. Tarragona: 187-234.
PayÀ Mercè, X., Pérez Almoguera, A. (2005). Ilerda, fonts i arqueologia d'una ciutat oculta. A: Actes del XV Simposi de la Secció Catalana de la S.E.E.C. Estudis Clàssics: Imposició, Apologia o Seducció? Lleida: 63-109.

Pérez Almoguera, A. (1998). Tres casos de rituales fundacionales o propiciatorios en construcciones domésticas en el Alto Imperio romano. ¿Latinidad o indigenismo? ARYS, 1: 195-206.

Quesada SANZ, F. (2012). Sobre caballos, caballeros y sacrificios cruentos en la Roma republicana y en Hispania. A: M. R. García Huerta, F. Ruiz Gómez (eds.). Animales simbólicos en la Historia. Desde la Protohistoria hasta el final de la Edad Media. Síntesis. Madrid: 111-132.

Ribera i Lacomba, A. (2010). Depósitos rituales de Valentia (Hispania). De la primera fundación republicana (138 aC) a la segunda Augustea. A: I riti del costruire nelle acque violate. Atti del Convegno Internazionale Roma, Palazzo Massimo 12-14 giugno. 2008. Ed. Science e Lettere. Roma: 269-294.

Ruiz de Arbulo, J. (1997). Ritos domésticos y cultos funerarios. Ofrendas de huevos y gallináceas en villas romanas del territorio emporitano (siglo III dC). Pyrenae, 28: 211-227.

Vazouez Falip, M. P., González Pérez, J. R., Medina Morales, J., María Mata Perelló, J. M., Rodríguez Duque, J. I. (2005). Actividades siderúrgicas en yacimientos de la primera Edad del Hierro próximos a la confluencia de los ríos Cinca, Segre y Ebro. A: Minería y metalurgia históricas en el Sudoeste europeo. Madrid del 23 al 27 de junio de 2004. Madrid: 129-145. 